Yenen, Alp. "Elusive Forces in Illusive Eyes: British Officialdom's Perception of the Anatolian Resistance Movement." Middle Eastern Studies 54, no. 5 (2018): 788-810. https://doi.org/10.1080/00263206.2018.1462161

This is a post-print version of the peer-reviewed and accepted manuscript. Be aware that there are some minor corrections in citation style, orthography, and punctuation in the final published version.

\title{
Elusive Forces in Illusive Eyes: British Officialdom's Perception of the
} Anatolian Resistance Movement

Alp Yenen

Middle Eastern Studies, University of Basel, Basel, Switzerland

\begin{abstract}
In the aftermath of the First World War, British officials had difficulty understanding the elusive forces behind the Anatolian resistance movement. They anxiously assumed that Kemalists were being controlled by the Unionist leaders in exile and that they were part of an international conspiracy. In this confusion, the fugitive Unionist leaders received disproportionate attention and credit in British intelligence reports, with critical consequences for their political sense-making and decision-making. I argue that the preconception of 'Young Turks' in general as well as assumptions about Unionist leaders' alleged and actual activities after 1918 were crucial for British officialdom's policies towards the Anatolian resistance movement.
\end{abstract}

Keywords: intelligence; conspiracy theory; Turkish War of Independence; Young

Turks; Mustafa Kemal Atatürk; Enver Pasha

The armistices of 1918 did not lift the fog of war. Rather, war and revolution continued beyond the official end of the First World War, clouding the vision of those trying to make sense of Europe's increasingly unruly peripheries. ${ }^{1}$ In the former Ottoman territories, uncertainties over the post-war settlement cleared only in 1922 and 1923. In the intervening years, the colonial plans of the victorious Allies to parcel out as mandates the Muslim-majority lands in and around the Ottoman Empire were challenged by protests, uprisings, revolutions, and wars of liberation. Unlike post-war resistance movements elsewhere in the Middle East, the Anatolian resistance movement would actually achieve full independence after both a successful paramilitary and military as well as a political and diplomatic struggle.

The 'National Struggle' (Milli Mücadele) in Anatolia, or the 'War of Independence' (Ístiklal Harbi or Kurtuluş Savaşı) as it is commonly called in Turkey, was an armed struggle against the occupation forces of Greece, Italy, France, and Britain as well as a war against the Armenian Republic in the north-eastern frontier. ${ }^{2}$ This 'National Struggle' was accompanied by continued violence against Ottoman Greeks and Armenians as well as by a civil war against the loyalist forces of the Sultan's government 
and groups who opposed or defected from the Anatolian resistance movement. ${ }^{3}$ For outside observers, the internal workings of this resistance movement in the distant and inaccessible region of Anatolia remained difficult to decipher.

Contemporary British officials, as I will illustrate in this article, frequently had difficulties in understanding the elusive forces behind the Anatolian resistance movement, especially regarding the degree to which they were connected to other anticolonial uprisings in the wider Muslim world. ${ }^{4}$ This article follows and extends A.L. Macfie's observation and argument that 'British perceptions regarding the nature and identity of the national movement in Anatolia remained confused throughout the period of Turkish national struggle'. ${ }^{5}$ The thin line between cooperation and competition that characterised relations between the two factions referenced in British intelligence reports - namely 'Unionists', i.e. the devotees of the 'Young Turk' Committee of Union and Progress (CUP), and the so-called 'Kemalists', i.e. the followers of Mustafa Kemal Pasha and his Ankara Government - was a matter of particular confusion and suspicion. ${ }^{6}$

British officials' perceptions of the Anatolian resistance movement were refracted through their understanding of the Young Turk movement. First, initial misconceptions about the Constitutional Revolution of 1908 provided a distorted blueprint in understanding the nature and agency of the Young Turk movement. A combination of Orientalist prejudices and conspiracy beliefs contributed to the obscure depiction of the Young Turk movement as a cabal of outlandish and sinister conspirators acting at the behest of 'international Jewry'. ${ }^{7}$ British suspicions towards the Young Turks were, however, more objectively substantiated by their strained experiences with the Young Turk regime between 1908 and 1918. British officials were convinced that Young Turks were reckless rulers and cunning conspirators responsible for war mongering and war crimes. Second, after the end of the First World War, British officials were dazzled by the complexity of the post-war resistance movements in the Middle East. Anxious imperial minds constructed conspiracy theories about a 'Muslim menace' spread by 'Bolshevik propaganda' and 'Young Turk intrigues', resulting in misperceptions of the Anatolian resistance movement. ${ }^{8}$ Lastly, increasing diplomatic interactions after 1921 supported by more accurate intelligence led British officials to gradually change their perception of the Ankara Government. In the chaos of post-war struggles, Kemalists came to be perceived as the lesser evil, one with whom Britain could eventually come to terms.

Misconceptions and misperceptions of the Young Turks were, of course, not the only factor that coloured British officials' sense-making and decision-making. ${ }^{9}$ Nevertheless, I will argue that the lack of reliable intelligence from Anatolia combined with faulty preconceptions about Young Turks and a simultaneous cacophony of information and disinformation regarding conspiratorial activities paved the way for the formation of rather delusional theories about what was occurring in Anatolia.

On the one hand, the activities in exile of the CUP's fugitive leaders, Enver Pasha and Talat Pasha, heightened the imperial anxieties of British observers. While the CUP was justifiably suspected of carrying out conspiratorial activities against the peace settlement, many intelligence analyses added a 'leap in imagination' in their interpretations of the CUP's actual role in grand schemes of unrest in the Middle East. ${ }^{10}$ Many British officials believed that the Kemalists were being controlled by the CUP leaders from their clandestine exile. The CUP leaders were constantly suspected of being part of an international conspiracy of Bolsheviks and Germans against British rule in Asia. Although not totally unfounded, these suspicions were mostly exaggerated and empirically misplaced. In this confusion, the CUP leaders in exile received 
disproportionate attention and credit in British intelligence and news reports, with critical consequences for their perception of the Anatolian resistance movement.

On the other hand, the actual role local Unionist networks played in the initial organization of the Anatolian resistance movement increased confusion about who was actually in charge in Anatolia. ${ }^{11}$ There is indeed an undeniable continuity and connection between the Unionists and the later Kemalists, which official histories of the Kemalist Republic tried to erase by constructing an epistemological rupture not only between empire and republic but also between Unionism and Kemalism. ${ }^{12}$ Therefore, many critical scholars today see intended and unintended continuities from Unionists to Kemalists in the brutal policies of nation and state building in Anatolia. ${ }^{13}$ Nevertheless, despite obvious ideological continuities and prosopographical commonalities, we also need to be cautious in equating the Unionists with the Kemalists as a single constituency when studying political movements in interactive and contentious processes up close. Indeed, it was the mix of these commonalities and hair-splitting distinctions that made both Kemalists and Unionists so elusive in the eyes of distant observers; the latter, meanwhile, were sometimes too keen to maintain certain illusive perceptions.

\section{Making the Case Against the Young Turks}

Assessment of intelligence, whether it serves espionage, security, military, or diplomacy, is always a matter of culture. Human intelligence is commonly produced through communication networks of central and peripheral power brokers and processed through various epistemological scripts. Fears and rumours can change how intelligence is assessed. ${ }^{14}$ British officials' assessment of intelligence on the Middle East was rooted in and filtered through contemporary Orientalist and colonialist pretences. A myriad of socalled 'gentleman spies' emerged in Victorian and Edwardian Britain who, in addition to being academically trained or self-taught Orientalists, Arabists, dragomans, and pundits, were imperial adventurers as well as colonial entrepreneurs. ${ }^{15}$ These new imperial agents, who could 'go native' in exotic countries, were culturally celebrated and employed by the empire as intuitive connoisseurs of the mysteries of the Orient and as empathetic experts in reading the erratic and enigmatic minds of Orientals. ${ }^{16}$ Famous Orientalistcum-colonialist entrepreneurs like T.E. Lawrence and Gertrude Bell, but also countless others, played crucial roles in the unmaking of the Ottoman Empire and the making of the modern Middle East - both epistemologically and geopolitically.

To understand British officials' assessment of intelligence relating to the Anatolian resistance movement after 1918, it is necessary to understand the initial defects in the way British officials and Orientalists perceived the Young Turk movement as it came to prominence. The revolution of 1908 was explained by many British officials in Constantinople to their colleagues in London through the medium of certain cultural scripts and conspiracy beliefs. As the prevailing paradigm of Orientalism denied the possibility of an indigenous Muslim agency behind the unexpected Constitutional Revolution of 1908, it was explained, in conspiracy theories, as having been caused by the incitement of foreign and hidden hands. Symptomatic of contemporary European conspiracy thinking, tropes of anti-Semitism were utilized in making sense of the Young Turk movement's secretive agency. The Young Turk movement was portrayed as a Jewish-Freemason conspiracy against British interests in the Middle East. ${ }^{17}$ Both antiSemitism and Orientalism were the offspring of the same Western discourse to divide, deny, and define the identity and agency of Europe's cultural others. ${ }^{18}$ Britain was no exception when it came to anti-Semitism. ${ }^{19}$ Gerald Fitzmaurice, the chief dragoman of 
the British embassy at the Ottoman capital, was the most influential promoter of a 'grand Middle Eastern conspiracy theory that was generally - but far from universally believed: that of Jewish and Freemason control of the Turkish revolution of 1908 ' ${ }^{20}$ Fitzmaurice and others were puzzled by the fact that some 'Jews, Socialists and Freemasons' were associated with the CUP. ${ }^{21}$ Hence, Fitzmaurice and like-minded contemporaries concluded that the Young Turks were under the spell of - if not themselves the embodiment of $-\mathrm{a}$ Jewish-Freemason conspiracy.$^{22}$ T.E. Lawrence remembered that Fitzmaurice convinced British officials that the Young Turks consisted of overall ' $50 \%$ crypto-Jew and 95\% Freemason' elements and the whole movement was, in Fitzmaurice's own words, 'harnessed to the chariot of Panjudaism'. ${ }^{23}$ Fitzmaurice's anti-CUP position was not limited to diplomatic correspondence either, as it became a popular rumour among Young Turks that the counterrevolution of 1909 was supposedly supported by Fitzmaurice from the British Embassy. ${ }^{24}$ The British ambassador Gerard Lowther explained the 'elusive' nature of the conspiracy between Jews and Young Turks as follows:

The Jew can help the Young Turk with brains, business enterprises, his enormous influence in the press of Europe, and money in return for economic advantages and the eventual realisation of the ideals of Israel, while the Young Turk wants to regain and assert his national independence and get rid of the tutelage of Europe as part of a general Asiatic revival, on lines and at a pace which must appear chauvinistic to the average Western. The Jew has supplied funds to the Young Turks and has thus acquired a hold on them; but in order to retain this hold he has to appear at least to approve and aid the Young Turk towards the accomplishment of "national" dreams. Secrecy and elusive methods are essential to both. The Oriental Jew is an adept at manipulating occult forces, and political Freemasonry of the continental type has been chosen as the most effective bond and cloak to conceal the inner workings of the movement. ${ }^{25}$

The misconception that Jews were the 'mainspring of the C.U.P.', to quote Sir Gilbert F. Clayton, director of Intelligence at Cairo during the First World War, and that the Young Turks were in Lowther's words 'self-seeking spurious freemasons' was not limited to a small circle, but instead consistently reproduced and propagated by official decision makers and public opinion makers after $1908 .{ }^{26}$ Regardless of its analytical use in political sense-making, one must note that anti-Semitism in itself never became a driving force of British decision-making. Once combined with political Orientalism in the Saidian sense, however, the fantasies of individual imperial agents could impact imperial and colonial affairs. ${ }^{27}$ British officials' Orientalist and anti-Semitic framing of the Young Turks would have a lasting impact on the historiography of the Young Turks as a cabal of crypto-Jews, Freemasons, pseudo-Muslims, Atheists, and Zionists. ${ }^{28}$

Obvious contrary evidence, for example that most members of the CUP were actually Turkish and Muslim nationalists, was explained away as a tactical deception by the mysterious conspirators. Lowther wrote, for instance, that although the 'Young Turkey movement is seriously influenced by Jewish and atheistic political Freemasonry', its followers 'paradoxically endeavour to use the Islamic fervour of the masses as a political weapon and to divert it into chauvinistic channels on the lines of national, i.e. Asiatic, Pan-Islamism' ${ }^{29}$ Imperial anxieties and Orientalist theories about the potential threat of pan-Islamism had existed since the 1860s. ${ }^{30}$ Sultan Abdülhamid's pan-Islamism had more or less represented an imperial policy of securing the sovereignty of the Ottoman Empire in international affairs. ${ }^{31}$ The Young Turk Revolution, however, triggered further geopolitical concerns regarding questions of popular sovereignty in 
British-ruled Egypt and India. The Foreign Secretary Sir Edward Grey cautioned, 'If Turkey really establishes a Constitution and keeps it on its feet, and becomes strong herself, the consequences will reach further than any of us can yet foresee. The effect in Egypt will be tremendous, and will make itself felt in India. ${ }^{32}$ Faced with the unexpected and unexplained Young Turk challenge, however, Britain chose to adopt a policy of moderation and reconciliation, but remained deeply suspicious and cautious of the Young Turks.

British officialdom's perception of the Young Turks was soon substantiated through more objective observations between 1908 and 1918. One did not need to be a believer in obscure conspiracy theories to see that the CUP was deeply involved in conspiratorial politics. The long list of their shadowy activities include assassinations, blackmailing, terrorism, purges, corruption, propaganda, sabotage, coups, revolutionary warfare, and genocide. The CUP that came to power after the revolution of 1908 and the coup d'état of 1913 was practically a komitadji (guerrilla) organization of Macedonian origins, shaped by the culture of insurgency and counterinsurgency typical of the Balkan provinces. ${ }^{33}$ Even after establishing an official Union and Progress Party (Ittihad ve Terakki Firkasi) for the purpose of constitutional politics in 1908, the Committee (Cemiyet) not only continued to dominate policy-making but also retained paramilitary bands of volunteers and racketeers. ${ }^{34}$ These paramilitary and parapolitical characteristics of the CUP regime substantiated the general perception of the Young Turks as rogue revolutionaries, cunning conspirators, and devious despots.

During the Great War, conspiratorial politics continued to be a feature of the Young Turk regime. Britain cautiously rejectedthe CUP's pre-war offers of alliance, leaving Germany as the only available partner as the Ottomans entered their third year of constant war since 1911. ${ }^{35}$ The British assumption that the Young Turks had pro-German inclinations from the outset was not only wrong, but was connected to widespread beliefs in a conspiracy that Jews were partners of German imperialism. ${ }^{36}$ The Young Turk regime's decision to enter the war on the side of the Central Powers was in fact conspiratorial - 'a political coup of the first order', as one historian noted - not because of such international collaboration, but because not even all of the Ottoman cabinet members were informed about the decision before it took effect. ${ }^{37}$ The war was accompanied by conspiracies and intrigues on all fronts, as all belligerent parties attempted to incite revolts and revolutions in the societies of enemy states. Soon after entering the war, the CUP extended its revolutionary activities to the wider Muslim world, threatening British colonial interests through the declaration of a 'great jihad' (cihad-l ekber). The Ottoman military's unconventional warfare organization known as the "Special Organization" (Teşkilat-ı Mahsusa), and the German Intelligence Bureau for the Orient (Nachrichtenstelle für den Orient) were eager to incite and propagate a revolutionary jihad. These efforts confirmed the already growing British fears of a 'Muslim menace' in their colonial dominions. ${ }^{38}$ Imperial anxieties of a pan-Islamic revolution against colonialism were an important force in British policy-making towards the Ottoman Empire throughout the war. Although the Ottoman-German jihad of 19141918 failed as a 'test-stone to the solidarity of Islam', to quote Lord Curzon, it nevertheless contributed to the Orientalist assumption that Muslim uprisings were not a normal consequence of colonial rule but provoked by outlandish conspirators. ${ }^{39}$ The conviction of the CUP regime as a gang of sinister conspirators was reconfirmed with the arrival of the first news and rumours of the Armenian Genocide. ${ }^{40}$

Anti-Semitic tropes continued to be a part of British thinking about the CUP regime. In 1917, for instance, R.W. Seton-Watson, the intellectual architect of the post- 
imperial Balkans and one of the War Office's intelligence and propaganda officers, professed that the Young Turks were 'almost all ... conspirators rather than politicians' and subordinated to the Jews because the 'real brains of the [Young Turk] movement were Jewish or Judæo-Moslem'. Seton-Watson concluded that ' $[\mathrm{t}]$ he main fact about the Committee of Union and Progress is its essentially un-Turkish and un-Moslem character'. ${ }^{41}$

After the Bolshevik Revolution of 1917, anti-Semitic conspiracy theories of world revolution once again gained worldwide currency. Like the Young Turk Revolution of 1908, the Russian Revolution of 1917 was widely received by British policy making circles as further evidence of a Jewish world conspiracy. ${ }^{42}$ In November 1918, shortly after the armistice, the senior Foreign Office official Sir Eyre Crowe noted that 'the heart and soul of all revolutionary and terroristic movements have invariably been the Jews, the Bolsheviks and the Turkish Committee of Union and Progress'. ${ }^{43}$

The case against the Young Turks was first based on Orientalist and anti-Semitic misconceptions about the Young Turk movement but then further substantiated by actual evidence of the CUP's shadowy policies in times of revolution and war. For these reasons, British officialdom maintained a habitual suspicion of the CUP. This conviction was not universally shared, but was dominant. For example, protesting 'the Foreign Office proTurk gang', Sir Mark Sykes insisted at the end of the war that the CUP leaders were nothing but 'masters in the old art of chicane' and Britain's policy was 'pledged to Zionism, Armenian liberation, and Arabian independence'. ${ }^{44}$

\section{The Persistence of the Young Turks}

After the Armistice of Mudros that ended the First World War in the Middle East, Unionist leaders fled the Ottoman capital for clandestine exile in Germany in order to escape being court martialled for war-mongering and crimes against humanity. Before their departure, however, they held secret meetings to invest their parapolitical authority in the ringleaders of the CUP's underground and paramilitary branches, so that the latter could continue the fight against the conditions of the armistice. ${ }^{45}$ Talat Pasha ordered his men to organize an underground civilian network of national resistance called Karakol Cemiyeti (Sentinel Society). ${ }^{46}$ Meanwhile, Enver Pasha instructed his followers in the

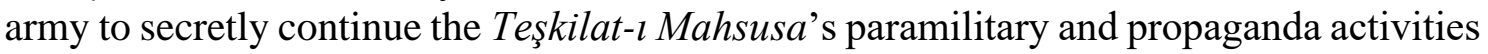
against the Allies throughout the Muslim world: 'You will officially dissolve the Teşkilat-ı Mahsusa, but in reality this organization will never cease to exist. ${ }^{, 47}$

By issuing orders like these, Enver and Talat, despite no longer having any official state post, remained qualified in the eyes of their fellow Committee men to represent the nation, the state, and the empire. This parapolitical agency constituted the CUP's elusive power as a 'government of the shadows'. ${ }^{48}$ The CUP's plans and initiatives for armed resistance against the armistice were to fall on fertile ground in Anatolia, especially in regions with intercommunal conflicts. ${ }^{49}$ Massacres against the remaining Armenian population in Cilicia started even before the end of 1918 and continued in increasing frequency until the French occupation. ${ }^{50}$ Meanwhile, CUP-associated local guerrillas were committing attacks against the Greek population in Western Anatolia. ${ }^{51}$ The CUP's underground networks and enduring influence played a major role in the initial organization and mobilization of the Anatolian resistance movement. ${ }^{52}$

Nevertheless, the CUP's role in Anatolia was also magnified by the imperial anxiety over a general uprising in the Muslim world. The Young Turk leaders' 
disappearance after the armistice sent sensationalist rumours into circulation. In the spring of 1919, the British received more and more conflicting intelligence about Enver Pasha's whereabouts, which placed him anywhere from Morocco to Berlin or Afghanistan. ${ }^{53}$ British intelligence held the Young Turk leaders responsible for the revolution in Egypt, the Kurdish uprisings in Iraq, and the palace revolution in Afghanistan. ${ }^{54}$ Meanwhile, an exhaustive report on the CUP and its activities was prepared by the British High Commission in Constantinople on 7 April 1919, which was still very much preoccupied with the Freemason and crypto-Jewish elements within the CUP and their alleged influence. ${ }^{55}$

Therefore, when the Anatolian resistance movement started in the spring of 1919, British officials immediately suspected the fugitive CUP leaders in exile of being behind the unrest. In a cacophony of intelligence reports, an official conspiracy theory was collectively constructed. 'A number of reports have been recently received, from a variety of sources', wrote Vice-Admiral A. Calthorpe from Constantinople to the British Embassy in Switzerland, where 'increased activity among Egyptian Nationalists, Committee of Union and Progress Turks, and Indian Nationalists' was observed. ${ }^{56}$ Intelligence reports confirmed existing fears of a concerted Muslim revolt directed from Berlin, Switzerland, and Moscow. The CUP leaders, together with Bolshevik agitators and German Orientalists, were suspected of being behind the Muslim revolts. An intelligence report also claimed to confirm that the 'C.U.P. is still strongly organized in Turkey and that a revolution was being secretly prepared which would, to say the least, cause anxiety to the Allied forces of occupation' ${ }^{57}$

Although accurate in mapping the anti-British resentments among Muslim activists in exile, many of these intelligence reports were simply misleading regarding the state of CUP leaders' political agency and operational reach. The fugitive CUP leaders were still in the early stages of their political reorganization in exile. Communication with the Middle East, including Constantinople and Anatolia, was extremely limited. Enver Pasha, sick and shipwrecked in Crimea, did not arrive in Berlin before late July 1919. ${ }^{58}$ Talat Pasha was holding meetings in European coffee houses and planning propaganda and protest activities, but such plans represented more civilian political activism than revolutionary conspiracy to incite distant uprisings. Neither Enver nor Talat had any contact with the Bolsheviks before August or September 1919 and enjoyed no substantial support from the German government except for semi-official protection from extradition to the Ottoman and Allied authorities. Claims about their subversive influence in these early months of the armistice that projected Talat and Enver as larger-than-life figures were unfounded conspiracy theories - despite the coincidence that they resembled the megalomaniac fantasies of the suspected conspirators.

Nonetheless, local and autonomous CUP networks in Constantinople and Anatolia were in fact a crucial force within the Anatolian resistance movement. The CUP's underground branches in Constantinople and Anatolia were autonomous cells working without a hierarchical command structure that linked them to the exiled CUP leaders. They were following some contingency plans for armed resistance prepared during the war - if not the imperatives of their political culture of subversion and usurpation. Such activities lent a false credence to one of the most common rumours circulating at the time, that Enver Pasha was in Azerbaijan and controlling the Anatolian resistance movement from there. British intelligence reported, for instance: 
At its best the National Defence Organization is credited with being in close touch with Azerbaidjan, while Enver Pasha directs the movement from Najhitchevan [Nakhchivan] [...].

Pan-Islamic, Bolshevist, Pan-Turkish and all disgruntled forces are looked for help and all are being toyed with. ${ }^{59}$

Similar rumours soon reached commanders of the National Struggle in the area. 'According to news received', reported the commander of the Eastern Front Kazım Karabekir Pasha to Mustafa Kemal Pasha, 'it is said [söylenmekte olup] that the forces, approaching the Akhurian River on behalf of the Bolsheviks, are commanded by Enver Pasha [...] ${ }^{60}$ Rumours that Enver was controlling the resistance movement reached their climax in the autumn of 1919. 'I beg to express the opinion that the whole movement originates with Enver Pasha', reported Captain Perring stationed at Samsun. ${ }^{61}$ His superior officer, Admiral Richard Webb had doubts, however 'I do not agree with his opinion' that 'the movement [is] originating with Enver', he responded, because 'other reports rather go to show that Mustafa Kemal has no dealings with him whatever' ${ }^{62}$ Such claims and counter-claims continued to confuse British officials and were not resolved until 1921. Enver would certainly have wished to be everywhere he was rumoured to be seen, but in reality he even had trouble travelling from Berlin to Moscow between October 1919 and August 1920.

The commanders of the 'National Forces' (Kuva-yı Milliye) were also not happy being associated with Enver Pasha and the Unionists. In addition to the CUP's notoriety in the eyes of the international public, many patriotic elites and common people also considered - for good reason - the CUP leaders to be reckless warmongers, devious despots, and inauspicious harbingers of imperial collapse and human suffering. In reality, however, Unionists, i.e. former and current CUP advocates, were indispensable to and indistinguishable from the personnel of the Anatolian resistance movement. After Mustafa Kemal Pasha claimed the leadership of the Anatolian resistance movement, he publicly distanced himself from the CUP and dismantled Unionist networks. At the Sivas Congress in September 1919, one of the founding congresses of the Anatolian resistance movement, Mustafa Kemal insisted that the delegates give an oath to the congress renouncing any loyalty to the CUP. ${ }^{63}$ Besides concerns about the public stigma of the CUP, Mustafa Kemal was trying to hinder a possible re-institutionalisation of CUP elements as an autonomous political organisation that could challenge his rise to power. ${ }^{64}$ Meanwhile, the sultan's government in Constantinople was systematically demonising the Anatolian resistance movement in diplomatic and public statements as a violent usurpation attempt by radical CUP remnants. ${ }^{65}$ Anti-CUP purges by the sultan's government began in March 1919 and led to the arrest and deportation of a number of CUP members to detention camps in the Crown Colony of Malta. ${ }^{66}$ A Kemalist official reported from Constantinople: 'What the opposition here is most fervently trying to do is to convince everybody that the nationalist movement is a Unionist movement and that Talat and Enver will soon come into power. ${ }^{97}$ Mustafa Kemal replied personally: 'On any given occasion, we did not hold back from denying that we have anything to do with Unionism. ${ }^{68}$ In an interview of October 1919, Mustafa Kemal stated that '[i]t is untrue that we are working with Enver Pasha. We believe his policies injured Turkey. We do not know his whereabouts. ${ }^{99}$ Kazım Karabekir Pasha, who was one of the officials most insistent in preempting alleged CUP schemes, reported that the news of Enver entering Anatolia from the Caucasus was 'absolutely a lie' and warned of 'propaganda about the national movement being a mandate of the Unionists' ${ }^{70}$ All these false rumours were 'nothing but fuss'. ${ }^{71}$ Meanwhile, British officials continued to believe that Enver was in 
Azerbaijan and exercising influence on the nationalist movement. ${ }^{72} \mathrm{~A}$ British memorandum at that time described the elusive power of the CUP in typically sensationalist and mysterious language:

It is fair to assume that the Committee of Union and Progress in one form or another will continue to control Turkish politics and the Sultan and his Government. Their policy is imperialistic both at home and abroad; it is definitely against any form of foreign interference (whether British or French). [...]

The Committee's strength [...] cannot be "controlled" by the physical power of the Allies nor can the Allies physically control the Committee. All the members and its organization are not known. Its ramifications are wide. ${ }^{73}$

While dismissing theories that gave Enver Pasha preeminence in directing the Anatolian resistance, Kazım Karabekir Pasha propagated his own conspiracies about the activities of the former Minister of War. In his book, Enver Pasha and the Union and Progress Leaders during our War of Independence, Karabekir claimed that 'During the War of Independence many plots also included Enver Pasha. Documents show that foreign hands played an incredible role in all such efforts in order to drag our national movement into a fiasco.' Karabekir even believed that Enver was an agent of British intrigues. ${ }^{74}$ Karabekir may have been a member of the opposition against Mustafa Kemal in the early Republican years and the author of one of the first counter-narratives of the War of Independence, but when it came to Enver, he also contributed to the official historiographical consensus of the Kemalist Republic. ${ }^{75}$ Foreign and hidden hands, including those behind Enver and his CUP gang, were perceived as working against 'Turkish' national sovereignty over Anatolia.

The CUP leaders in Berlin had only limited correspondence with the Anatolian resistance movement in 1919 and 1920. The CUP leaders in German exile established contact with Mustafa Kemal Pasha only in early $1920 .{ }^{76}$ Talat Pasha openly offered to subordinate himself to Mustafa Kemal and the Anatolian resistance movement if he would be formally authorised to coordinate clandestine and public activities in Europe. This was partly granted by Mustafa Kemal at a moment when the fate of the Anatolian resistance movement was particularly precarious. The correspondence between Mustafa Kemal and Talat was, however, criticised within the leadership of the Anatolian resistance movement. 'On what occasion and according to which commission's decision was a courier sent to Enver Pasha and Talat Pasha?' asked another official in Anatolia. ${ }^{77}$ Although the Kemalist movement was now in loose contact with the CUP leaders, Mustafa Kemal remained determined not to be perceived as a servant of Unionism. 'By this, we would be labelled as Unionists', Mustafa Kemal warned Talat and this 'would give our enemies a weapon and chance to diminish our strength' ${ }^{78}$

As soon as Ankara's ability to find allies abroad improved, Mustafa Kemal backed off from his preliminary overtures to Talat and his friends. After the Kemalist delegations arrived at Moscow, the CUP leaders were disowned by Ankara as representatives in negotiations with Soviet Russia. 'It cannot be permitted', Mustafa Kemal wrote to Kazım Karabekir, "that Enver Pasha and his fellows intervene independently and of their own accord in the affairs of homeland and the nation. ${ }^{79}$ The Ankara Government soon released an official decree declaring that 'Talat, Cemal, and Enver Pashas have no authority to engage in any political enterprise in the name of the Grand National Assembly, nor do they have any communication or association with us' ${ }^{80}$ 
The question of ownership over the Anatolian resistance movement was increasingly becoming a Machiavellian concern for Mustafa Kemal. This concern would mark the main argument of his later grand lecture (Nutuk) on the War of Independence the core source of the Turkish nationalist historiography. Mustafa Kemal would there argue that he alone had possessed the single vision and agency during the crisis and everybody else was either a patriotic follower of his guidance or a reactionary traitor and jealous usurper against the national cause. ${ }^{81}$

\section{The Anatolian Resistance as Part of an International Conspiracy}

British perceptions of the Anatolian resistance movement were especially distorted when viewing the struggle as part of a connected and concerted anticolonial Muslim uprising joining North Africa, the Middle East, and India. There were, in fact, certain transnational connections between different Muslim movements and a global cause and context to rebel against colonialism, but this did not amount to the grand conspiracy so often portrayed by the British. ${ }^{82}$ Pan-Islamism once again came to be perceived as a major threat to the British Empire after 1919. Assistant Under-Secretary of State at the India Office Arthur Hirtzel argued that 'Panislamism is undoubtedly a danger - a potential danger. The antidote is nationalism.' Hirtzel believed, like many others, that 'the nationalist movement if properly guided \& controlled will tend against Panislamism [...]'. ${ }^{83}$ 'Our aim must be to divide and to conciliate, and to rule,' argued another British official unapologetically, 'because we do not want Moslems to rally as a whole round the fundamental but at present half-forgotten principle that Moslems should not be ruled by non-Moslems. ${ }^{84}$

While British officialdom saw the CUP leaders engaged in anti-British conspiracies everywhere possible, ironically both Talat Pasha and Enver Pasha were trying to come to terms with British decision-makers. During secret meetings in Berlin from August 1919 to February 1920, Major Ivor Hedley, a member of the British Military Mission in Berlin, held secret negotiations with the fugitive CUP leaders. British documents report that Talat 'practically offered his services' to establish 'a united Turkey [...] in the Turkish-speaking territories of Europe and Asia'. Enver, too, claimed to the British official that 'an independent Turkey closely and secretly associated with Great Britain' would solve their 'difficulties and dangers in Egypt and other Mahommedan countries further East'. Enver self-confidently exaggerated the CUP's organizational reach and seditious capacities. ${ }^{85}$ Regarding his relation to Mustafa Kemal Pasha, Enver claimed boldly to the British - playing on their obvious confusion - that Mustafa Kemal 'was willing [...] to take his orders from Enver if necessary, thus though appearing to be still enemies, they would in reality be working for the same ends for their country' ${ }^{86}$ This was, again, a deception - if not a self-deception on Enver's part. When Major Hedley asked Enver, 'if [...] he intended to modify his anti-English campaign throughout Islam or continue the very wide active propaganda that he meditated', Enver answered that 'it would now be very difficult to break it off'. This was simply a matter of deterrence, as he had not undertaken any serious actions in this direction. Enver knew very well that he possessed an elusive power rooted in the constant overestimation of his potential influence. If the British would agree to work with him, however, Enver offered to break ongoing relations with the Bolsheviks. Enver made clear that 'his presence would be essential if the feeling towards England is to be entirely changed' ${ }^{87}$ In reality, besides some negotiations with the Bolshevik leader Karl Radek and Soviet representative Viktor Kopp in Berlin, the fugitive CUP leaders had achieved little so far. After hearing reports 
about Hedley's continued conversations with Enver, Lord Curzon ordered him to abandon 'any such intercourse with a criminal whose surrender has been demanded from Germany' ${ }^{88}$ But for many other British officials, Enver was too dangerous and scheming to be simply let off the leash. ${ }^{89}$

The Kemalist movement likewise sought to project an elusive profile in the eyes of critical observers. ${ }^{90}$ The way the Kemalists appeared did not much differ in this phase from how British officials imagined the Unionists: as a band of rogue revolutionaries collaborating with the sinister forces of pan-Islamism and Bolshevism against the British Empire. Not Turkish nationalism as commonly assumed, but rather Islamic solidarity and Muslim nationalism dominated the political rhetoric of the Anatolian resistance movement. ${ }^{91}$ From spring 1919 to spring 1921, the Anatolian resistance movement also had its 'Bolshevik moment', in which some socialist ideas and material support of Soviet Russia were openly demanded. ${ }^{92}$ It remains disputed whether Mustafa Kemal's rhetorical flirtation with Islamic and Bolshevik ideas was merely opportunistic. ${ }^{93}$ It is still not unreasonable to view the overtures to Islamic solidarity and Bolshevik ideals as curious considerations of a collective mentality in the crisis of foreign occupation and colonial partition. In the spring of 1920, lacking any concrete evidence of organisational links between Unionists and Kemalists in Anatolia and the Bolsheviks in Moscow, the British Intelligence chief in Constantinople still argued: 'We are looking for something far more elusive and intangible than that $[\ldots] .{ }^{, 94}$

The expansion of Bolshevik propaganda targeting the colonised world gave a further boost to British conspiracy theories. In September 1920, newspaper and intelligence reports confirmed Enver Pasha's presence at the Baku Congress, where Bolshevik leaders called on the Muslim world to wage a holy war against the imperialists and capitalists. The rumours and conspiracy theories circulating since November 1918 finally seemed to be confirmed - remarkably at a time when the anticolonial unrest in the Middle East had reached its climax in Anatolia, Syria, Palestine, and Iraq. ${ }^{95}$ A British intelligence report stated that 'active cooperation has been obtained between Syria and Anatolia', in which 'a violent and well organized pan-Islamic policy has been instituted both in Syria and Angora'. The report concluded: 'Controlling influence in the movement is C.U.P., though it has combined pan-Arab and nationalist elements as well as tribes. [...] Great endeavours are being made to unite Moscow and Enver Bey with the above. ${ }^{96}$ Although Arabs and Turks did have opportunity to collaborate, Bolshevik influence did not reach as far as the Levant and Mesopotamia. ${ }^{97}$

Many British officials were still under the spell of conspiracy thinking in their interpretations. Major Norbert N. E. Bray, a special intelligence officer working for the India Office in Iraq, ${ }^{98}$ reported that the Middle Eastern unrest was a 'concerted action' directed by 'outside influence' of secret societies originating from Berlin and Moscow. ${ }^{99}$ This Bolshevik-CUP plot, in Major Bray's conspiracy theory-laden words, would 'throw out her sinister tentacles which, griping about in every direction, seek to fasten themselves on local soil, into which their roots will strike, giving her a fresh grip of organized conspiracy'. Therefore, he proposed, 'we must remember that our opponent is working on a highly organized and single-minded system; we have to oppose an organized resistance'. ${ }^{100}$ This was simply a ragbag of paranoid buzzwords denying the bitter truth that wide-spread anticolonial sentiments and indigenous agency were actually responsible for the great unrest in the Middle East. ${ }^{101}$

Not only British officials but also numerous public voices were reproducing the same conspiracy theory-laden discourse. Reacting to the fact that many Bolshevik leaders at the Baku Congress were of Jewish origin, the Times noted that 'of all the strange things 
which have happened in the last few years, none has been stranger than this spectacle of two Jews, one of them a convicted pickpocket, summoning the world of Islam to a new Jehad' ${ }^{102}$ In early 1920, the infamous anti-Semitic propaganda pamphlet, The Jewish Peril: Protocols of the Learned Elders of Zion, was first published in English. ${ }^{103}$ The Morning Post published the Protocols in a series under the sensationalist heading 'The Cause of World Unrest' in which these were presented as an evidence for 'the existence of a vast Pan-Oriental Conspiracy'. ${ }^{104}$ In David Fromkin's words, 'the Protocols explained - among other things - the mysterious revolts against Britain everywhere in the East'. ${ }^{105}$ 'The Cause of World Unrest' series explained these connections as follows:

There is certainly a great similarity between the propaganda now being carried on in Asia and "the programme of violence and hypocrisy" advocated by the protocols. [...] The gospel they are secretly preaching is Pan-Oriental, and their desire is to shake authority in the States under Christian tutelage and to arouse anti-Christian sentiment in independent Eastern States. [...]

One of the objects of the secret conspiracy is "[...] to promote on other continents sedition, dissension, and mutual hostility." With this object in view the promoters of disorder, who have one of their most important headquarters in Switzerland, have portioned out the areas on which they are to work. Seditious literature and agents pass from Europe to Turkey, and their influence spreads by definite routes over Asia Minor to Persia and Afghanistan. ${ }^{106}$

Ironically, wild conspiracy theories helped the Kemalist movement to present itself as the lesser evil. A British intelligence report claimed that it was the Kemalist 'dislike of the Jewish Free-Masonic elements dominating the Unionists' that was partly responsible for the chasm between the two movements. ${ }^{107}$ One British official believed that besides the Kemalist faction there was a 'far more dangerous party, that of Enver \& Talaat \& the CUP-Jew-German-Bolshevik combination', which was 'with the PanIslamic offensive of Bolshevism throughout the East, primarily directed against Great Britain' ${ }^{108}$ A new differentiation between Kemalists and Unionists was in the making:

At present two main divisions of Nationalists; (a) genuine Nationalists following Mustafa Kemal; (b) a Unionist group [...]; but with Talaat and Enver and the C.U.P., in harmony with their Russian and German associates, providing the real guidance. Kemal's party desire to use the Bolsheviks to further Nationalist aims without adopting the Bolshevik organizations of Society. The Unionist group, whose ultimate purpose is Pan-Islamism, believe that nothing effective can be got from Bolshevism without accepting all the consequences of Bolshevism. ${ }^{109}$

The same report assumed that Mustafa Kemal would ultimately be outmanoeuvred by 'Bolshevik Unionists' who would even go so far as proclaiming the anti-British Emir Amanullah of Afghanistan as the new caliph of Muslims.

\section{Disillusionment and Settlement in Foreign Affairs}

By the end of 1920, Britain's foreign policy establishment started to see world affairs differently, particularly in relation to its role in the Middle East. ${ }^{110}$ To be sure, imperial anxieties about pan-Islamic-Bolshevik conspiracies were not the sole force of change. Kemalist Turkey was also increasingly looking for a rapprochement with the British Empire in order to certify its international sovereignty. Meanwhile, the Ottoman SultanCaliph Vahideddin was still propagating the same old story of un-Turkish Bolshevik 
bandits to the British High Commissioner in Constantinople. This story, however, achieved considerably less impact at a time when the Kemalist diplomat Bekir Sami Bey had already been invited to London. ${ }^{111}$

The attitude of the Ankara Government was also becoming more resolute against the CUP leaders abroad. On 12 March 1921, the Grand National Assembly in Ankara decided that Enver Pasha and his friends would not be allowed to enter Anatolia. ${ }^{12}$ Behind this decision were the increasing rumours that Enver would march into Anatolia with a Red Army division. Fevzi Pasha, the Ankara Government's minister of national defence, had intelligence that the British were propagating rumours that Enver's 'Green Army' was ready to implement Bolshevism in Anatolia. ${ }^{113}$ It was believed that British intelligence officials were spreading pseudo-Bolshevik propaganda to turn the Ankara Government against Soviet Russia. ${ }^{114}$ Ironically, the Ankara Government was soon reproducing the same rumours and paranoid conspiracies about Enver's alleged Bolshevik invasion and spreading active propaganda against Enver. ${ }^{115}$

Ankara's friendship agreement with Soviet Russia in March 1921, which sealed the bitter fate of the Armenian Republic at the Caucasus frontier, ${ }^{116}$ further increased British imperial anxieties, as Enver was believed to be the Bolshevik's trump card against Mustafa Kemal. With the Anatolian resistance movement struggling against Greek offensives in early summer 1921, British officials believed 'the Bolsheviks would prefer to see Enver in control of the Nationalist movement'. ${ }^{117}$ 'I think', noted another British official in Constantinople, 'that there can be no doubt that Enver and Committee of Union and Progress are gradually taking command of situation at Angora and that Kemalist Government must be [regarded as entirely] in the hands of Bolsheviks.'118 'Enver is doubtless scheming to be the Deus ex Machina', assumed another British official, who suggested that Enver wanted to 'repeat his sensational performance of 1913 when he reentered Adrianople'. ${ }^{119}$ Enver and his supporters indeed harboured very similar dreams of his heroic return to rescue the homeland in the late summer of 1921. Contrary to British anxieties and Enver's hopes, however, Ankara-Moscow relations were working against the realisation of Enver's desires in Anatolia. ${ }^{120}$

The rumours of a potential Bolshevik take-over in Ankara under Enver Pasha's leadership served to make Mustafa Kemal Pasha appear as the moderate party in the eyes of British officials. A report to Lord Curzon claimed: 'Mustapha Kemal and his Minister, while anxious to show themselves not less zealous than the extremist group which looks to Enver Pasha, are in reality anxious to cut adrift from the Bolsheviks and so compromise with the Allies.' ${ }^{121}$ The British representative in Constantinople reported to London: 'If Kemalist defeat was indeed decisive there would very likely be an anti-Kemalist movement in Anatolia, but I feared it might result in a Bolshevik-Enver combination with the object of continuing the war to the bitter end. ${ }^{, 22}$

A potential Bolshevik coup d'état by Enver Pasha became redundant after the defeat of the Greek forces at the Battle of Sakarya by the Ankara Government's army on 13 September 1921. Enver accordingly gave up on Turkey and desperately headed towards Turkestan to try his luck anew. The British high commissioner in Constantinople still reported to London in late November 1921 that 'there are persistent rumours that Enver Pasha is proving to be a thorn in the side of Mustapha Kemal'. ${ }^{123}$ The British Intelligence had again lost track of Enver's movements and was dwelling on incidents from the previous summer. 'All that can be assured is that Enver is making a strong effort to re-enter Turkish politics, and has supporters in Angora and doubtless in the army, especially among those who favour a more whole-hearted co-operation with the Bolsheviks. ${ }^{124}$ Unaware that Enver went to Turkestan to fight against Soviet Russia, 
British intelligence was still reporting on the autonomous Enverist opposition in Anatolia in the familiar tropes of conspiracy thinking, namely that 'the strings of the opposition are pulled by Turks and Salonica crypto-Jews in Berlin and Switzerland'. ${ }^{125}$

While Britain was increasingly reluctant about further supporting the Greek occupation, France had already approached the Ankara Government to bring an end to the hostilities on the southern front of the National Struggle. The Ankara Government signed the Ankara Treaty with France on 20 October 1921. Andrew Orr, a historian of French intelligence, writes that 'French government's opening to the Kemalists was an attempt to prevent a feared Middle East-wide rebellion'. ${ }^{126}$ The same fears were all too familiar to British officials.

The degree to which Enver Pasha had become a spectre in Anatolian affairs was illustrated in a peculiar episode in the summer of 1922. Only months before the Ankara forces' final victory against the remaining Greek occupying army, the 'anti-Kemalist' newspaper Peyam- $\iota$ Sabah in Constantinople published a very odd editorial that caused great curiosity. ${ }^{127}$ To everybody's surprise, the newspaper's editor Ali Kemal Bey celebrated Enver's struggle against Soviet Russia in Turkestan, although the author was known to be a vocal anti-Unionist. One British official supposed that Ali Kemal was trying to pave the way for an alliance between the two anti-Kemalist blocks in Turkey, namely pro-Entente Sultanists and pro-Enver Unionists. ${ }^{128}$ Both Kemalists and Unionists were rather puzzled by this peculiar editorial. ${ }^{129}$ The British intelligence report, however, assumed a (potential) conspiracy between the Sultan Vahideddin and Enver as 'a possible means of destroying Mustafa Kemal'. For the 'lack of positive evidence', it was, nevertheless, admitted that 'the suggestion that they are coming together as being for the moment no more than a theory which must be tested by close observation of future developments'. The possible ramifications of Enver returning to power, however, were considered more horrendous for British interests than the prospect of coming to terms with Ankara, as the British report concluded: 'I doubt if we could swallow Enver for the sake of the Sultan, even to get rid of Kemal. ${ }^{130}$

\section{Conclusion}

Historians have discussed in detail the ambiguous continuities between the CUP and what later became the Kemalist movement, critiquing the latter's self-presentation as a caesura in the history of the nation and revealing it as having origins both less novel and darker. ${ }^{131}$ Yet, as I have argued above, these elusive commonalities and distinctions among two Young Turk factions also had an effect on international relations. Decision-making in international relations is always a matter of perceptions and misperceptions. ${ }^{132}$ The ambiguous relations between the CUP and the Kemalists was a cause of confusion and concern for foreign powers such as Britain.

Thanks to the Orientalist and anti-Semitic conspiracy thinking prevailing in the British intelligence community, the CUP was envisaged after the Young Turk Revolution of 1908 as an elusive force changing disguises, transgressing natural boundaries, and conspiring with, or even driven by, sinister forces like Jews, Freemasons, and Germans. British officials' observation of the CUP's very real conspiratorial politics between 1908 and 1918 supported the case against the Young Turks as a gang of rogue revolutionaries and cunning conspirators. After ten years of dictatorial rule, the CUP had indeed obtained parapolitical capacities in the Ottoman Empire and its networks retained influence even after its leaders' departure. As a clandestine and conspiratorial committee, it constituted 
an elusive force confusing and deceiving outsiders about its intentions and actions. In the end, the paranoid interpretations of international conspiracies contained in intelligence reports magnified and distorted the CUP's illusive agency. The fact that some variation of 'Young Turks' - in the figurative sense of the word - were rebelling in Anatolia and giving vocal support to other Muslim uprisings led many British observers to falsely assume that it was the hidden hand of the CUP leaders abroad that was pulling the strings. As A.L. Macfie observed, paranoid intelligence reports about Enver's pan-IslamicBolshevik activities were an important factor in the reconciliation of British policy makers with the Ankara Government. ${ }^{133}$ The existence of bogus conspiracy theories does not categorically dismiss the evidence of real conspiracies, and vice versa, but rather distorts the origin, nature, and reach of conspiratorial agency through epistemological scripts, ontological paranoias, and conscious speculations. ${ }^{134}$ This distinct qualification does not contradict but rather substantiates our understanding of how the CUP leadership and its distant and disconnected networks contributed directly and indirectly to the Anatolian resistance movement and how the exiled CUP leaders were engaged ambitiously but unsuccessfully in a transnational anticolonial movement among Muslim activists in European exile.

Most of the intelligence reports theorising that the CUP leaders were commanding the Anatolian resistance movement from abroad were composed within the timeframe of early 1919 and autumn 1920, when the CUP leaders were relatively inactive or unsuccessful. As Enver Pasha and his transnational enterprise became increasingly active and apparent after September 1920, and the Ankara Government established itself as a sovereign quasi-state, the perception that the two factions were linked together within a grand conspiracy gradually began to disappear. The initial British confusion was not completely unfounded either. By their nature, Kemalists and Unionists were elusive forces. They were the same but distinct; they were simultaneously allies and rivals; while separate, they were actually inseparable from each other. Despite their shared struggle, Kemalists and Unionists were reluctant collaborators. They were competing for the same goals, opportunities, and resources. In a heterogeneous political movement like the Anatolian resistance movement, differentiations between such similar but rival factions are important, especially because outside observers could not always tell them apart or confused their relations. Andrew Ryan, Fitzmaurice's successor as the Chief Dragoman and a very vocal voice in the official conspiracy theories, confessed in his later memoirs:

I feared political pan-Islamism. It looked as though Mustafa Kemal might make that his instrument as Enver had almost certainly dreamt of doing. I did not see much difference, so far as I remember, between Kemal's group and the old Committee of Union and Progress, apart from a struggle for leadership. [...]

I cannot now claim that all these views were right. I can only say that they were tenable at the time. Subsequent events disproved some of them, notably the fear of pan-Islamism. That virus was driven out for an indefinite period by the stronger virus of nationalism. ${ }^{135}$

In the fog of war, the preconceptions and anxieties of an 'Enver \& Talaat \& the CUP-Jew-German-Bolshevik combination' plotting a global jihad against the colonial world order coloured British officialdom's perceptions of the Anatolian resistance movement. The ambitious but ambiguous actions and assertions by the CUP leaders abroad lent credence to such conspiracies and stoked the fears of British officials. The Kemalist leadership's elusive overtures with Islamic and Bolshevik ideas as well as their ambiguous relation to Unionists similarly caused confusion. While the rumours of 
'Young Turk intrigues' initially enhanced British hostility towards the resistance movement in Anatolia, British officials eventually chose to come to terms with the more 'moderate' Kemalist movement.

\section{Acknowledgements}

I am grateful for the comments and corrections offered by Funda Soysal, Daniel-Joseph MacArthur-Seal, and Alexander Balistreri as well as the anonymous reviewers.

Needless to say, I am alone responsible for the remaining errors.

\section{Notes}

1 Robert Gerwarth, The Vanquished: Why the First World War Failed to End 1917-1923 (New York: Farrar, Straus and Giroux, 2016).

2 For a well-balanced introductory survey see: Hasan Kayal1, 'The Struggle for Independence', in The Cambridge History of Turkey: Turkey in the Modern World, Vol. 4, ed. Reşat Kasaba (Cambridge: Cambridge University Press, 2008), pp.112-46.

3 Ryan Gingeras, Sorrowful Shores: Violence, Ethnicity, and the End of the Ottoman Empire, 1912-1923 (Oxford: Oxford University Press, 2009), pp.81-135.

4 I would like to thank Foti Benlisoy (Istos Press, İstanbul) for calling my attention to this differentiation that conspiracy thinking is more common in macro-intelligence analyses than in micro-intelligence reports.

5 A.L. Macfie, 'British Intelligence and the Turkish National Movement, 1919-22', Middle Eastern Studies Vol. 37, No. 1 (2001), p.9.

6 I do not use the term 'Kemalist' in its popular sense, referring to ideological followers of 'Kemalism'. Even before Mustafa Kemal Atatürk developed his Kemalist doctrine in the late 1920s and 1930s, many contemporary Western sources used the term 'Kemalist' from 1919 to 1923 as an alternative term for the 'Nationalist forces' under Mustafa Kemal's leadership.

7 This issue has been studied in greater detail in Nabeel Audeh, 'The Ideological Uses of History and the Young Turks as a Problem for Historical Interpretation: Considerations of Class, Race, and Empire in British Foreign Office Attitudes towards the Young Turks, 1908-1918' (PhD thesis, Georgetown University, 1990).

8 Some of these misperceptions are reproduced, for instance, in Salahi R. Sonyel, 'Mustafa Kemal and Enver in Conflict, 1919-22', Middle Eastern Studies Vol. 25, No. 4 (1989), pp.506-15. 
9 For more detailed studies on British misperceptions and miscalculations in the post-war Middle East see: David Fromkin, A Peace to End All Peace: The Fall of the Ottoman Empire and the Creation of the Modern Middle East, 1989, 20th anniversary ed. (New York: Henry Holt \& Co., 2009); Isaiah Friedman, British Miscalculations: The Rise of Muslim Nationalism, 1918-1925 (New Brunswick: Transaction Publishers, 2012).

10 In his classic account on conspiracy thinking, Hofstadter writes: 'What distinguishes the paranoid style is not, then, the absence of verifiable facts (though it is occasionally true that in his extravagant passion for facts the paranoid occasionally manufactures them), but rather the curious leap in imagination that is always made at some critical point in the recital of events.' Richard Hofstadter, The Paranoid Style in American Politics and other Essays, 1965 (Cambridge: Harvard University Press, 1996), p.37.

11 Erik Jan Zürcher, The Unionist Factor: The Rôle of the Committee of Union and Progress in the Turkish National Movement 1905-1926 (Leiden: Brill, 1984).

12 Paul Dumont, 'The Origins of Kemalist Ideology', in Atatürk and the Modernization of Turkey, ed. Jacob M. Landau (Boulder: Westview Press, 1984), pp.25-44; Selim Deringil, 'The Ottoman Origins of Kemalist Nationalism: Namik Kemal to Mustafa Kemal', European History Quarterly Vol. 23, No. 2 (1993), 165-91; Erik J. Zürcher, 'The Ottoman Legacy of the Kemalist Republic', in The Young Turk Legacy and Nation Building: From the Ottoman Empire to Atatürk's Turkey (London: I.B. Tauris, 2010), pp.136-50.

13 Uğur Ümit Üngör, The Making of Modern Turkey: Nation and State in Eastern Anatolia, 1913-50 (Oxford: Oxford University Press, 2011).

14 Pioneering cultural approaches to intelligence history in British India are Christopher Alan Bayly, Empire and Information: Intelligence Gathering and Social Communication in India 1780-1870 (Cambridge: Cambridge University Press, 1996); Kim A. Wagner, The Great Fear of 1857: Rumours, Conspiracies and the Making of the Indian Uprising (Oxford: Peter Lang, 2010).

15 For a rather sympathetic account of gentleman spies see: John Fisher, 'Gentlemen Spies in Asia', Asian Affairs Vol. 41, No. 2 (2010), pp.202-12.

16 Priya Satia, Spies in Arabia: The Great War and the Cultural Foundations of Britain's

Covert Empire in the Middle East (Oxford: Oxford University Press, 2008), pp.99-135.

17 Elie Kedourie, 'Young Turks, Freemasons and Jews', Middle Eastern Studies Vol. 7, No. 1 (1971), pp.89-104.

18 Edward W. Said, Orientalism, 1978, 25th anniversary edition (New York: Vintage Books, 1994), pp.139-48.

19 On anti-Semitism in Britain before the outbreak of the First World War see: Kenneth Lunn, 'Political Anti-Semitism before 1914: Fascism's Heritage?', in British Fascism: Essays on 
the Radical Right in Inter-War Britain, ed. Kenneth Lunn and Richard C. Thurlow (London: Croom Helm, 1980), pp.20-40.

20 Satia, Spies in Arabia, p.204. On Fitzmaurice see: Geoff Berridge, Gerald Fitzmaurice (1865-1939): Chief Dragoman of the British Embassy in Turkey (Leiden: Martinus Nijhoff Publishers, 2007).

21 For the relation of 'Jews, Socialists and Freemasons' to the CUP see: A.L. Macfie, The End of the Ottoman Empire, 1908-1923 (New York: Longman, 1998), pp.30-38.

22 This conception in the historiography was first revised in Ernest E. Ramsaur, The Young Turks: Prelude to the Revolution of 1908 (Princeton: Princeton University Press, 1957), pp.103-8.

23 Robert Graves and Liddell Hart, T. E. Lawrence to his Biographers (New York: Doubleday, 1963), p.88; Fitzmaurice, letter (Constantinople) to Tyrrell, 5 November 1912, National Archives, Grey Papers, Foreign Office Papers (FO), 800.80, 3, quoted in Audeh, 'Ideological Uses of History', p.155.

24 Halide Edib [Adıvar]. Memoirs (London: John Wiley \& Sons, 1926), p.278. On Young Turk conspiracy theories that Fitzmaurice was himself a conspirator in the counterrevolution see: Feroz Ahmad, 'Great Britain's Relations with the Young Turks 1908-1914', Middle Eastern Studies Vol. 2, No. 4 (1966), pp.312-314; Doğan Avcığlu, 31 Mart'ta Yabancı Parmağl [Foreign Hands in the $31^{\text {st }}$ March Incident]. 1969, ed. Hadiye Y1lmaz (İstanbul: Kaynak Yayınları, 2013); Sina Akşin, Şeriatçı Bir Ayaklanma 31 Mart Olayı [The $31^{\text {st }}$ March Incident as a Reactionary Uprising]. 1970, 3rd ed. (Ankara: İmge Kitabevi, 1994), pp.267-9.

25 Lowther, letter (Constantinople) to Hardinge, 29 May 1910, Lowther Papers, FO.800.193A, reprinted in the appendix of Kedourie, 'Young Turks, Freemasons and Jews', p.100. 26 Clayton, letter (London) to Wingate, 3 August 1916, Wingate Papers, Sudan Archives, Durham University; Lowther, letter to Hardinge, 27 April 1910, Hardinge Papers, Vol. 20, p.235, Cambridge University Library. Both letters quoted in ibid. pp.91, 93.

27 Said, Orientalism, p.237.

28 Western and Middle Eastern historians continued to reproduce these misconceptions about Young Turks, as discussed in greater detail in Audeh, 'Ideological Uses of History', pp.545-82. This British conspiracy theory was rehashed by 'Islamicizing-revisionist' historians from Middle Eastern countries, depicting the Young Turks as Jews, Freemasons, Atheists, and Zionists. Maurus Reinkowski, 'Late Ottoman Rule over Palestine: Its Evaluation in Arab, Turkish and Israeli Histories, 1970- 90', Middle Eastern Studies Vol. 35, No. 1 (1999), pp.69-72, 74-75. For Islamist and secularist variants of this 1908 conspiracy theory in Turkey, see also: Marc D. Baer, 'An Enemy Old and New: The 
Dönme, Anti-Semitism, and Conspiracy Theories in the Ottoman Empire and Turkish Republic', Jewish Quarterly Review Vol. 103, No. 4 (2013), pp.523-55.

29 Lowther, letter (Constantinople) to Hardinge, 29 May 1910, Lowther Papers, FO.800.193A, in Kedourie, 'Young Turks, Freemasons and Jews', pp.103, 99. Emphasis mine.

30 Imperial anxieties prior to 1908 are explored in John Ferris, “"The Internationalism of Islam": The British Perception of a Muslim Menace, 1840-1951', Intelligence and National Security Vol. 24, No. 1 (2009), pp.59-62; Michael C. Low, 'Empire and the Hajj: Pilgrims, Plagues, and Pan-Islam under British Surveillance, 1865-1908', International Journal of Middle East Studies Vol. 40, No. 2 (2008), pp.269-90. A prominent example of conspiracy thinking about pan-Islamism is W.W. Hunter, The Indian Musalmans: Are They Bound in Conscience to Rebel against the Queen? (London: Williams and Norgate, 1871).

31 On Abdülhamid's pan-Islamism see: Selim Deringil, 'Legitimacy Structures in the Ottoman State: The Reign of Abdulhamid II (1876-1909)', International Journal of Middle East Studies Vol. 23, No. 3 (1991), pp.345-59.

32 Grey, letter (London) to Lowther, 31 July 1908, Grey Papers, F.O. 800.78, quoted in Ahmad, 'Great Britain's Relations with the Young Turks', p.303; similar remarks by Hardinge are cited in Joseph Heller, British Policy Towards the Ottoman Empire 1908-1914 (London: Frank Cass \& Co., 1983), p.11.

33 George W. Gawrych, 'The Culture and Politics of Violence in Turkish Society, 1903-14', Middle Eastern Studies Vol. 22, No. 3 (1986), pp.307-30; Ryan Gingeras, Heroin, Organized Crime and the Making of Modern Turkey (Oxford: Oxford University Press, 2014), pp.25-29.

34 For the troublesome relations between the Committee and the Party of the Union and Progress see: Tarık Zafer Tunaya, Türkiye'de Siyasal Partiler III: Ittihat ve Terakki [Political Parties in Turkey III: Union and Progress] (İstanbul: Hürriyet Vakf1 Yayınları, 1989), pp.200-214, for the CUP's paramilitary branches, pp.273-99. See also: Nader Sohrabi, 'Illiberal Constitutionalism: The Committee Union and Progress as a Clandestine Network and the Purges', in L'Ivresse de la liberté: La révolution de 1908 dans l'Empire ottoman, ed. François Georgeon (Leuvain: Peeters, 2012), pp.109-20.

35 Ahmad, 'Great Britain's Relations with the Young Turks', pp.321-25.

36 Lowther, letter (Constantinople) to Hardinge, 29 May 1910, Lowther Papers, FO.800.193A, in Kedourie, 'Young Turks, Freemasons and Jews', pp.103. How anti-Semitic and antiGerman attitudes were interlinked is discussed in Colin Holmes, Anti-Semitism in British Society: 1876-1939 (London: Arnold, 1979), pp.121-40; Panikos Panayi, “"The Hidden Hand": British Myths about German Control of Britain During the First World War', Immigrants \& Minorities Vol. 7, No. 3 (1988), pp.253-72. 
37 F.A.K. Yasamee, 'Ottoman Empire', in Decisions for War, 1914, ed. Keith M. Wilson (London: UCL Press, 1995), p.237. See also: Mustafa Aksakal, The Ottoman Road to War in 1914: The Ottoman Empire and the First World War (Cambridge: Cambridge University Press, 2008).

38 Tilman Lüdke, Jihad Made in Germany: Ottoman and German Propaganda and Intelligence Operations in the First World War (Münster: LIT-Verlag, 2005), pp.62-70.

39 Ferris, “"The Internationalism of Islam”, pp.62-64, Curzon's quote on p.64.

40 On initial British reactions see: Donald Bloxham, The Great Game of Genocide: Imperialism, Nationalism, and the Destruction of the Ottoman Armenians (Oxford: Oxford University Press, 2005), pp.136-39. On British reactions throughout the war see: Michelle Tusan, “"Crimes against Humanity": Human Rights, the British Empire, and the Origins of the Response to the Armenian Genocide', The American Historical Review Vol. 119, No. 1 (2014), 56-64.

41 R. William Seton-Watson, The Rise of Nationality in the Balkans (London: Constable, 1917), pp.134-36.

42 On the British perception of the Russian Revolution as a Jewish conspiracy see: Sharman Kadish, Bolsheviks and British Jews: The Anglo-Jewish Community Britain and the Russian Revolution (London: Frank Cass, 1992), pp.10-55.

43 Crowe, minute, 18 November 1918, FO.371.4369.513, quoted in John Fisher, 'British Responses to Mahdist and Other Unrest in North and West Africa, 1919-1930', Australian Journal of Politics and History Vol. 52, No. 3 (2006), p.348.

44 Quoted in Friedman, British Miscalculations, p.6.

45 Hüsamettin Ertürk, İki Devrin Perde Arkası [Behind the Scenes of Two Periods], ed. Samih N. Tansu (İstanbul: Sebil Yayınevi, 1996), pp.164-70. See also: A. A. Cruickshank, 'The Young Turk Challenge in Postwar Turkey', Middle East Journal Vol. 22, No. 1 (1968), pp.18-20.

46 Halil Kut, Ittihat ve Terakki'den Cumhuriyet'e Bitmeyen Savaş [Endless War from Union and Progress to the Republic], ed. Taylan Sorgun (İstanbul: Kum Saati Yayınlar1, 2007), pp.202. For the activities of the Karakol Cemiyeti see: Fethi Tevetoğlu, Milli Mücadele Ylllarındaki Kuruluşlar: Karakol Cemiyeti, Türkiye'de Ingiliz Muhibleri Cemiyeti, Wilson Prensibleri Cemiyeti, Yeşilordu Cemiyeti [Organisations During the National Struggle Years: The Sentinel Society, the Society of Anglophiles of Turkey, the Society of Wilson's Principles, the Green Army Society] (Ankara: Türk Tarih Kurumu Yayınları, 1988), pp.350; Nur Bilge Criss, Istanbul under Allied Occupation, 1918-1923 (Leiden: Brill, 1999), pp.97-114; Erol Ülker, 'Sultanists, Republicans, Communists: The Turkish National Movement in Istanbul, 1918-1923' (PhD thesis, University of Chicago, 2013), pp.14-39.

47 Ertürk, İki Devrin Perde Arkası, p.167. 
48 Eric M. Wilson, 'Deconstructing the Shadows', in Government of the Shadows: Parapolitics and Criminal Sovereignty, ed. Eric M. Wilson (New York: Pluto Press, 2009), pp.13-55. 49 Kayal1, 'Struggle for Independence', p.119.

50 Bloxham, The Great Game of Genocide, pp.152-3.

51 Gingeras, Sorrowful Shores, pp.55-80.

52 Zürcher, Unionist Factor, p.168.

53 Masayuki Yamauchi, ed., The Green Crescent under the Red Star: Enver Pasha in Soviet Russia, 1919-1922 (Tokyo: Institute for the Study of Languages and Cultures of Asia and Africa, 1991), pp.11-12.

54 Alp Yenen, 'The Young Turk Aftermath: Making Sense of Transnational Contentious Politics at the End of the Ottoman Empire, 1918-1922' (PhD thesis, University of Basel, 2016), pp.117-50.

55 FO.605.115. See also: Mehmet Okur, 'İstanbul İngiliz Yüksek Komiserligi'nin İttihat ve Terakki Cemiyeti'ne Dair Bir Raporu' [A Report by the British High Commissioner in Istanbul on the Committee of Union and Progress], in Ittihatçılar ve Itttihatçıllk Sempozyumu: 25 Kasim 2014, Ankara: Bildiriler [Unionists and Unionism Symposium: 25 November 2014, Ankara: Papers], 3 Vols. (Ankara: Türk Tarih Kurumu Yayınları, 2015), Vol. 1, pp.1-32.

56 Calthorpe, letter (Constantinople) to British Embassy (Berne), 4 May 1919, FO.371.3717.123065, p.102.

57 Hugh Whittall, 'The Nearer East and the British Empire', 5 June 1919, FO.371.4142.90575, pp.76.

58 Murat Bardakçı, ed., Talat Paşa'nın Evrak-ı Metrukesi: Sadrazam Talat Paşa'nın Özel Arşivinde Bulunan Ermeni Tehciri Konusundaki Belgeler ve Hususi Yazışmalar [Talat Pasha's Remaining Papers: Documents on the Armenian Deportation and Other Private Correspondence Found in Grand Vizier Talat Pasha's Private Archive] (İstanbul: Everest, 2009), pp.152-58.

59 Heathcote-Smith, report (Constantinople) on the 'Activities of the National Defence Organization', 24 July 1919, FO.371.4158.118411, p.6.

60 Kazım Karabekir, report to the Third Army Inspector Mustafa Kemal Pasha, 22 June 1919, Genelkurmay Askeri Tarih ve Stratejik Etüt Başkanlığı Arşivi (Turkish General Staff’s Directorate for Military History and Strategic Studies, in short ATASE), Atatürk Collection (ATAZB), BoxBox No. 17, File No. 7.

61 Perring, report (Samsun) to de Robeck (Constantinople), 1 October 1919, FO.406.41. p.292, No. 139-1 in Bilal N. Şimşir, ed. British Documents on Atatürk (1919-1938), (in short BDA) 8 Vols. (Ankara: Türk Tarih Kurumu Yayınları, 1973-2006), Vol. 1, p.159. 
62 Webb, report (Constantinople) to Curzon, 18 October 1919, FO.406.41. p.291-292, No. 139 in ibid. p.158.

63 Mazhar Müfit Kansu, Erzurum'dan Ölümüne kadar Atatürk'le Beraber [Together with Atatürk from Erzurum until His Death], 4th ed., 2 Vols. (Ankara: Türk Tarih Kurumu Yayınları, 1997), Vol. 1, p. 219. British officials were aware of the formal disavowal of the CUP at the Sivas Congress. Andrew Ryan, The Last of the Dragomans, ed. Reader Bullard (London: Geoffrey Bles, 1951), pp.135-37.

64 Emine Kısıklı, 'Milli Mücadele Başlangıcında, Mustafa Kemal Paşa’nın Milli Hareketi, İttihat ve Terakki Faaliyetlerinden Uzak Tutma Teşebbüsleri’ [Mustafa Kemal Pasha’s Attempts to Keep the National Movement away from the Activities of the Committee of Union and Progress], Ankara Üniversitesi Türk Inkılap Tarihi Enstitüsü Atatürk Yolu Dergisi, No. 5 (1990), pp.109-27; Sina Akşin, İç Savaş ve Sevr'de Ölüm [Civil War and Death at Sèvres] (İstanbul: Türkiye İş Bankası Kültür Yayınları, 2010), pp.292-304.

65 Osman Akandere and Hasan A. Polat, 'Damat Ferit Paşa Hükümetleri Tarafindan Kuva-yı Milliyecilere Yöneltilen İttihatçılık Suçlamalarının Boyutları' [The Dimensions of Unionist Accusations against the National Forces by the Damat Ferit Pasha Governments], in Ittihatçılar ve İttihatçılık Sempozyumu, Vol. 1, pp.227-52.

66 Bünyamin Kocaoğlu, Mütarekede İttihatçılık: İttihat ve Terakki Fırkasının Dağılması (19181920) [Unionism During the Armistice: The Disintegration of the Party of Union and Progress (1918-1920)]. (İstanbul: Temel Yayınları, 2006), pp.187-250.

67 Şevket, cipher (Constantinople) to 3rd Army Corps, 12 October 1919, ATASE, ATAZB, BoxBox No. 9, File No. 83.

68 Mustafa Kemal, cipher (Sivas) to Şevket (Constantinople), 10 October 1919, ATASE, ATAZB, Box No. 9, File No. 83.

69 United States Radio Press, Nationalist Party in Turkey, 15 October 1919, FO.406.41. p.299, No. 140-5 in Şimşir, BDA, vol. 1, pp.171.

70 Kazım Karabekir, cipher (Van) to Ministry of War, 1 November 1919, ATASE, İstiklal Harbi Koleksiyonu (War of Independence Collection, hereafter, İSH), Box No. 197, File No. 224.

71 Kazım Karabekir, cipher (Erzurum) to Ministry of Foreign Affairs, 3 December 1919, ATASE, İSH, Box No. 45, File No. 51.

72 Military Intelligence (Constantinople), 'Weekly Summary of Intelligence Reports', 26 February 1920, FO.371.5166. E-1782 in Şimşir, BDA, Vol. 1, pp.426-27.

73 Adam, memorandum (Paris) on 'Constantinople and the Straits', 10 January 1920, in Documents on British Foreign Policy 1919-1939, First Series, (in short DBFP) 27 Vols. (London: Her Majesty's Stationery Office, 1947-1986), Vol. 4, pp.1026-27. 
74 My emphasis. Kazım Karabekir, İstiklal Harbimizde Enver Paşa ve İttihat-Terakki Erkanı [Enver Pasha and the Union and Progress Leaders During Our War of Independence] (İstanbul: Yap1 ve Kredi Yayınlar1, 2010), pp.7, 29-30, 32.

75 Erik J. Zürcher, 'Young Turk Memoirs as a Historical Source: Kazım Karabekir's İstiklal Harbimiz', Middle Eastern Studies Vol. 22, No. 4 (1986), pp.562-70.

76 Talat, letter (Berlin) to Cavid (Switzerland), 21 December 1919 in Hüseyin Cahit Yalçın and Osman Selim Kocahanoğlu, eds. İttihatçı Liderlerin Gizli Mektupları: Bir Devri Aydinlatan Tarihi Mektuplar [Secret Letters of the Unionist Leaders: Historical Letters that Shed Light on an Era] (İstanbul: Temel Yayınları, 2002), pp.145; diary entry, 27 December 1919, in Cavid Bey, Meşrutiyet Ruznamesi [Diary of the Constitutional Era], 4 Vols., ed. Hasan Babacan and Servet Avşar (Ankara: Türk Tarih Kurumu Yayınları, 20142015), Vol. 4, pp.52-53; Selim İlkin and İlhan Tekeli, 'Kurtuluş Savaşında Talat Paşa ile Mustafa Kemal'in Mektuplaşması' [Correspondence Between Talat Pasha and Mustafa Kemal During the War of Independence], Belleten Vol. 44, No. 174 (1980), pp. 309-15. 77 İsmet, cipher to Salih, 21 February 1920, ATASE, ATAZB, Box No. 23, File No. 110. 78 Mustafa Kemal, letter (Ankara) to Talat (Berlin), 29 February 1920 in Yalçın and Kocahanoğlu, İttihatçı Liderlerin Gizli Mektupları, pp.218.

79 Mustafa Kemal, letter (Ankara) to Kazım Karabekir (Erzurum), 30 May 1920, ATASE, İSH, Box No. 613, File No. 45.

80 Mustafa Kemal, letter (Ankara) to Kazım Karabekir (Erzurum), 20 June 1920, ATASE, İSH, Box No. 613, File No. 80.

81 Erik J. Zürcher, 'The Politician as Historian, Historians in Politics: On the Nutuk (Speech) of Mustafa Kemal Pasha', in The Young Turk Legacy and Nation Building, p.14; Howard L. Eissenstat, 'The Limits of Imagination: Debating the Nation and Constructing the State in Early Turkish Nationalism', (PhD thesis, University of California, 2007), pp.74-76.

82 Alp Yenen, 'The "Young Turk Zeitgeist" in the Middle Eastern Uprisings in the Aftermath of World War I', in War and Collapse: World War I and the Ottoman State, ed. M. Hakan Yavuz and Feroz Ahmad (Salt Lake City: University of Utah Press, 2016), pp.1181-1216. 83 Hirtzel, minute, 26 August 1919, quoted in John Ferris, 'The British Empire vs. The Hidden Hand: British Intelligence and Strategy and 'The CUP-Jew-German-Bolshevik combination', 1918-1924', in The British Way in Warfare: Power and the International System, 1856-1956: Essays in Honour of David French, ed. Keith Neilson and Greg Kennedy (Farnham: Ashgate, 2010), p.340.

84 Ryan, memorandum, 25 December 1919, in DBFP, Vol. 4, p.1003. 85 Hedley, notes on an interview with Enver Pasha, 6 January 1920, National Archives, War Office Papers (WO) 32.5620, quoted in Ferris, 'British Empire vs. Hidden Hand', pp.325. 
86 Hedley, notes on a second interview with Enver Pasha, n.d., WO.32.5620, quoted in ibid. p.335.

87 Hedley, report (Berlin) on a telephone conversation with Enver Pasha, 25 February 1920, FO.371.5211. E-1311, pp.39-40.

88 FO, letter to the Secretary of the Army Council, 26 March 1920, FO.371.5211. E-1311, p.42. 89 Ferris, 'British Empire vs. Hidden Hand', p.335.

90 These ambiguities are best summarised in Eissenstat, 'The Limits of Imagination', pp.67127.

91 Erik J. Zürcher, 'The Vocabulary of Muslim Nationalism', International Journal of the Sociology of Language Vol. 137, No. 1 (1999), pp.81-92.

92 Abdülhamit Kırmızı, 'After Empire, Before Nation: Competing Ideologies and the Bolshevik Moment of the Anatolian Revolution', in Revolutions and Counter-Revolutions: 1917 and its Aftermath from a Global Perspective, ed. Stefan Rinke and Michael Wildt, pp.119-37 (Frankfurt: Campus Verlag, 2017), here p.125. This argument is also put forward in Sabahattin Selek, Anadolu İhtilali [The Anatolian Revolution] (İstanbul: İstanbul Matbuas1, 1968); Emel Akal, Milli Mücadelenin Başlangıcında Mustafa Kemal, İttihat Terakki ve Bolşevizm [Mustafa Kemal, Union and Progress, and Bolshevism at the Beginning of the National Struggle], 3rd ed. (İstanbul: TÜSTAV Türkiye Sosyal Tarih ve Araştırma Vakfi, 2008).

93 M. Şükrü Hanioğlu, Atatürk: An Intellectual Biography (Princeton: Princeton University Press, 2011), pp.102-9.

94 Emphasis added. Report on 'Connection of Nationalists and Pan-Islamists with Russian Bolshevists', 5 May 1920, FO.371.5178. E-4689.

95 Alp Yenen, 'The Other Jihad: Enver Pasha, Bolsheviks, and Politics of Anticolonial Muslim Nationalism During the Baku Congress 1920', in The First World War and its Aftermath: The Shaping of the Middle East, ed. T. G. Fraser (London: Gingko Library Press, 2015), pp.273-93.

96 Secretary of State of India to Civil Commissioner (Baghdad), 23 September 1920, WO 106.200, quoted in Isaiah Friedman, British Pan-Arab Policy, 1915-1922: A Critical Appraisal (New Brunswick: Transaction Publishers, 2010), p.223.

97 Eliezer Tauber, 'Syrian and Iraqi Nationalist Attitudes to the Kemalist and Bolshevik Movements.' Middle Eastern Studies Vol. 30, No. 4 (1994), p.909.

98 Bray, 'Preliminary Report on Causes of Unrest in Mesopotamia', September 1920, FO.371.5230. E-12339, also CAB/24/112; 'Causes of the Unrest in Mesopotamia - Report No. II', September 1920, FO.371.5231. E-7765; 'An Examination of the Cause of the Outbreak in Mesopotamia', October 1920, WO.33.969. For a brief summary of these 
reports see: 'Relations Between Bolsheviks and Turkish Nationalists', November 20, 1920, FO.371.5178. E-14638.

99 Bray, 'Preliminary Report on Causes of Unrest in Mesopotamia', September 1920, FO.371.5230. E-12339, p.3.

100 Bray, 'Causes of the Unrest in Mesopotamia', September 1920, FO.371.5231. E-7765.

101 Satia, Spies in Arabia, p.204.

102 The Times, 'The Red Flag in the East', 23 September 1920.

103 Norman Cohn, Warrant for Genocide: The Myth of the Jewish World-Conspiracy and the Protocols of the Elders of Zion, 3rd ed. (Chico: Scholars Press, 1981), p.152.

104 Morning Post, 17, 21, 27 July and 4 August 1920, quoted in Susan Kingsley Kent,

Aftershocks: Politics and Trauma in Britain 1918-1931 (Basingstoke: Palgrave

Macmillan, 2009), p.60.

105 Fromkin, A Peace to End All Peace, p.469.

106 Howell A. Gwynne, ed., The Cause of World Unrest: With an Introduction by the Editors of 'The Morning Post' (of London) (London: G.P. Putnam's Sons, 1920), pp.180-81.

107 Report on 'Anatolian Affairs' (Constantinople), 12 August 1920, FO.371.5178. E-11072.

108 Osborne, minute, 23 September 1920, FO.371.4946. E11702.

109 Tyrrell, note on 'Anatolian Affairs', 12 August 1920, FO.371.5178. E-11072.

110 Richard W. Cottam, Foreign Policy Motivation: A General Theory and a Case Study

(Pittsburgh: University of Pittsburgh Press, 1977), pp.258-76.

111 Sir Horace Rumbold, letter (Constantinople) to Earl Curzon (London), 21 March 1921, in Şimşir, BDA, Vol. 3, pp.264-67.

112 Başbakanlık Cumhuriyet Arşivi [Prime Ministerial Republican Archives], BCA-030-0-018001-001-2-38-18.

113 Fevzi, letter (Ankara) to Southern Front Command (Antalya), 27 February 1921; 26 May 1921, ATASE, İSH, Box No. 742, File No. 8.

114 Fevzi, arrest warrant for Enver Pasha and his friends, 29 May 1921, in Murat Bardakçı, Enver (İstanbul: İş Bankası Yayınları, 2015), p.562.

115 Mustafa Kemal, letter (Ankara) to Kazım Karabekir (Erzurum), 3 June 1921, ATASE, İSH, Box No. 1167, File No. 115. It was only after the spring of 1921 that the Enverist factions in Anatolia started to pose a serious challenge to the Ankara Government. Yenen, 'The Young Turk Aftermath', pp. 432-53; Ülker, 'Sultanists, Republicans, Communists', pp.79-90.

116 Richard G. Hovannisian, 'Armenia and the Caucasus in the Genesis of the Soviet-Turkish Entente', International Journal of Middle East Studies Vol. 4, No. 2 (1973), pp.129-47.

117 Ryan, memorandum, n.d., enclosed in Rattigan, letter (Constantinople) to Curzon (London), June 8, 1921, FO.406/46, p.87-88, No. 61/1, in Şimşir, BDA, Vol. 3, p.371. 
118 Rattigan, letter (Constantinople) to Curzon (London), 8 July 1921, in ibid. pp.476.

119 Harington, letter (Constantinople) to the WO (London), 7 July 1921, FO.371.6473, E-8417.

120 Yenen, 'The Young Turk Aftermath', pp.414-5, 448-53.

121 Rattigan, letter (Constantinople) to Curzon (London), 12 July 1921, FO.406/47, pp.16-17, No. 10, in Şimşir, BDA, Vol. 3, p.511.

122 Rattigan, letter (Constantinople) to Curzon (London), 24 July 1921, FO.371.6524. E-8527, in ibid. pp.554-55.

123 Rumbold, letter (Constantinople) to Curzon (London), 29 November 1921, FO.406/48, p.91, No. 38, in Şimşir, BDA, Vol. 4, p.92.

124 Rumbold, letter (Constantinople) to Curzon (London), 29 November 1921, FO.406/48, p.93-94, No. 40, in ibid. pp.92-93.

125 Rumbold, letter (Constantinople) to Curzon (London), 24 January 1922, FO, 406/49, pp.68-70, No. 20, in ibid. pp.188-89.

126 Andrew Orr, “We Call You to Holy War”: Mustafa Kemal, Communism, and Germany in French Intelligence Nightmares, 1919-1923', The Journal of Military History Vol. 75 (2011), p. 1120.

127 Ali Kemal, 'Enver'in Yeni Celadetleri' [Enver's New Acts of Gallantry], Peyam-ı Sabah, 3 July 1922.

128 Henderson, letter (Constantinople) to Balfour, 11 July 1922, FO.7868, E-7072, in Şimşir, $B D A$, Vol. 4, p.301. For relations between 'Sultanists' and 'Enverists' in Constantinople in this period see: Ülker, 'Sultanists, Republicans, Communists', pp.92-98.

129 For an intelligence report of the Ankara officials dated 8 July 1922, mentioning Ali Kemal's article, see: Ankara Üniversitesi, Türk İnkılap Tarihi Enstitüsü Arşivi (Ankara University, Institute of the Turkish Revolution History Archives), Box No. 67, File No. 96. Enver Pasha's brother Kamil in Berlin considered this article by Ali Kemal as a signal from the British officials to reach a settlement with Enver Pasha in Central Asia. Kamil, letter (Berlin) to Enver (Turkestan), 10 July 1922, Türk Tarih Kurumu Arşivi (Archive of the Turkish Historical Society), Enver Pasha Collection, Box No. 01, File No. 86.

130 Henderson, letter (Constantinople) to Balfour, 11 July 1922, FO.7868, E-7072, in Şimşir, BDA, Vol. 4, p.302.

131 Besides the contributions to the continuity thesis by Zürcher, Dumont, Deringil, Eissenstat, and Üngör as cited above, see also the various contributions on the intellectual origins of the Kemalist Republic in Tanıl Bora and Murat Gültekingil, eds. Modern Türkiye'de Siyasi Düşünce I: Cumhuriyet'e Devreden Düşünce Mirast: Tanzimat ve Meşrutiyet'in Birikimi [Political Thought in Modern Turkey I: The Intellectual Legacy Inherited by the Republic: Heritage of the Tanzimat and the Constitutional Eras] (İstanbul: İletişim Yayınları, 2004). Long overdue credit belongs also to socio-economic historian İdris Küçükömer, who first 
formulated the continuity thesis between the Unionism and Kemalism in 1969, later republished in İdris Küçükömer, Düzenin Yabancılaşması: Batılaşma [Alienation of the Order: Westification] (İstanbul: Bağlam Yayınları, 2006). See also: Kurtuluş Kayalı, ‘Zürcher İdris Küçükömer Okudu Mu?’ [Did Zürcher Read İdris Küçükömer?], in Türk Kültür Dünyasından Portreler [Portraits from the Turkish Cultural World] (İstanbul: İletişim Yayınları, 2002), pp.123-24.

132 Robert Jervis, Perception and Misperception in International Politics (Princeton: Princeton University Press, 1976).

133 Macfie, 'British Intelligence and the Turkish National Movement', pp.14.

134 Jeffrey M. Bale, 'Political Paranoia v. Political Realism: On Distinguishing between Bogus Conspiracy Theories and Genuine Conspiratorial Politics', Patterns of Prejudice Vol. 41, No. 1 (2007), pp.45-60; Jovan Byford, Conspiracy Theories: A Critical Introduction (Houndmills: Palgrave Macmillan, 2011), pp.25-36.

135 Ryan, Last of the Dragomans, pp.171-72. 